Bulletin of the Natural History Museum, 2017, 10: 105-111.

Received 17 Nov 2017; Accepted 11 Dec 2017.

doi:10.5937/bnhmb1710105P

UDC: $599.42 / .44(497.11)$

Short communication

\title{
THE FIRST RECORD OF EUROPEAN FREE-TAILED BAT TADARIDA TENIOTIS (RAFINESQUE, 1814) IN SERBIA
}

\author{
BRANKA PEJIĆ $^{1 *}$, IVANA BUDINSKI ${ }^{1}$, BRANKO KARAPANDŽA ${ }^{2}$, MILAN \\ PAUNOVIĆ $^{3}$
}

${ }^{1}$ Department of Genetic Research, Institute for Biological Research "Siniša Stanković", University of Belgrade, Bulevar Despota Stefana 142, 11060 Belgrade, Serbia; branka.pejic@hotmail.com ivana.budinski@ibiss.bg.ac.rs

${ }^{2}$ Fauna C\&M, Zemunska19, 22304 Novi Banovci, Serbia; fauna.cm@gmail.com

${ }^{3}$ Natural History Museum, Njegoševa 51, 11111 Belgrade, Serbia; milan.paunovic@nhmbeo.rs

European free-tailed bat, Tadarida teniotis (Rafinesque, 1814) is the only representative of the Molossidae family in Europe. It has Palearctic distribution, but occurs mainly in the Mediterranean region (Fig. 1) (Benda \& Piraccini 2016, Dietz \& Kiefer 2016). In Europe, it is present on the Iberian Peninsula, in southern France, Switzerland, Italy, Slovenia (Presetnik in lit.), Croatia and the southern Balkan Peninsula (Benda \& Piraccini 2016).

The species roosts in inaccessible cliffs and rock crevices, often near the coastline or in mountainous regions up to $3,000 \mathrm{~m}$ above the sea level. Alternative roost sites can be fissures in cave ceilings, but also artificial objects resembling natural roosts, such as cracks in high buildings and bridges (Dietz \& Kiefer 2016, Paunović 2016). Tadarida teniotis forages primarily over forested areas, but also acts as an opportunistic forager depending on the temporary concentration of pray, so it also uses alluvial 
plains and valleys in mountainous regions, scrublands, lakes and urban areas (Marques et al. 2004). It flies high, 10-300 $\mathrm{m}$ above the ground, in straight and high-speed flight (up to $65 \mathrm{~km} / \mathrm{h}$ ), and therefore capturing this species using mist-nets is usually difficult. T. teniotis are capable of long forages (up to 10 hours without rest), usually within the radius of 20-100 $\mathrm{km}$ from their roosts, but they do not migrate seasonally (Marques et al. 2014, Dietz \& Kiefer 2016).

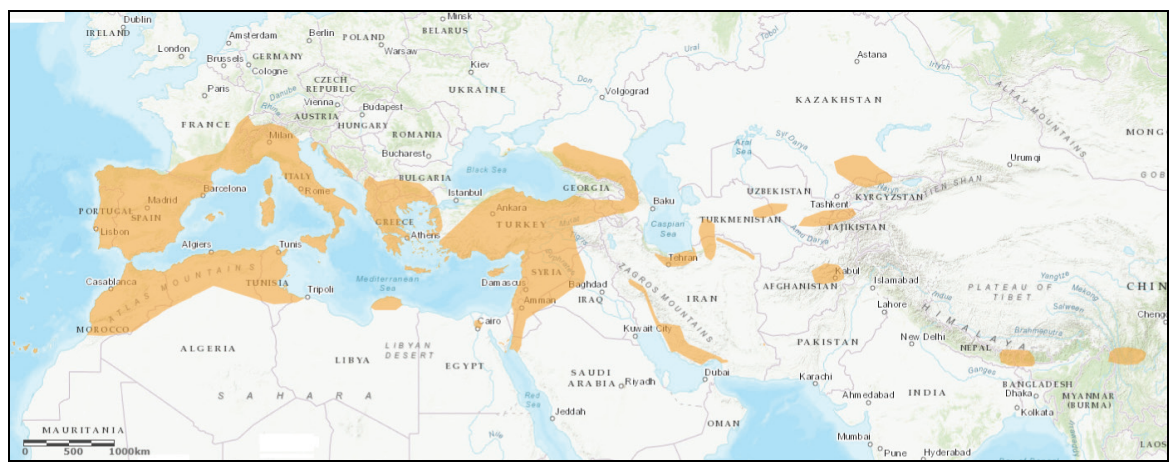

Fig. 1. - Distribution of Tadarida teniotis (Benda \& Piraccini 2016).

Pančić (1869) discussed the possibility of the presence of T. teniotis in Serbia, while Dokić (1883) later included this species in the mammal list of Serbia, however without specific details or locations. There was no further mention of the species until Ciechanowski et al. (2005) recorded it in Montenegro (State Union of Serbia and Montenegro at the time). Considering its presence in the neighbouring countries: Croatia (Domazetović \& Hamidović 2014), Bosnia and Herzegovina (Milanolo et al. 2017), Montenegro (Presetnik et al. 2014), Albania (Ramaj 2014), Macedonia (Micevski et al. 2014) and Bulgaria (Pandourski 2014), and suitable habitats at least in the southern parts of Serbia, the presence of this species in Serbia was to be expected (Paunović 2016).

According to the latest IUCN Red List (Benda \& Piraccini 2016), the status of the European free-tailed bat is LC (least concern). It is internationally legally protected by the Bonn Convention (Appendix II and EUROBATS Agreement) and Bern Convention (Appendix II) (Benda \& Piraccini 2016). It is not included in the current legislation of Serbia (Paunović 2016).

The protected area Landscape of the Outstanding Features (LOF) "Vlasina" is located at the farthest southeast part of the country (Fig. 2a), between the Južna Morava River valley and the Serbian-Bulgarian state border, in the territory of the Municipality of Surdulica (Belij \& Nešić 2014). This area is a mountainous landscape whose altitudes range from 1,200 to $1,850 \mathrm{~m}$ a.s.l. (Belij \& Nešić 2014) and are covered with 
deciduous (beech and rare moor birch) forests and coniferous plantations (Nedeljković et al. 2014).

The survey of bat fauna in the LOF "Vlasina" was conducted in the period 2015-2017, two times per year, by bioacoustic recording using Pettersson 240x (PetterssonElektronik AB, Uppsala, Sweden) time-expansion ultrasound detector and Record M ESI handheld audio recorder. All recorded bat calls were subsequently analysed using the BatSound 4.03 software (Pettersson Elektronik AB, Uppsala, Sweden), and the species were identified following Russo \& Jones (2002) and Boonman et al. (2009).

One of the recordings of echolocation calls made on 9 June 2015 near Vlasina Rid (Fig. 2b) $\left(42.743578^{\circ} \mathrm{N}, 22.328800^{\circ} \mathrm{E}, 1225 \mathrm{~m}\right.$ a.s.1.) during transect on the road along Vlasina Lake was suspected to be that of Tadarida teniotis. Unfortunately, the quality of the recording was low and it was impossible to unambiguously attribute the signal to this species. However, echolocation calls recorded on 18 October 2017, at 20:33, during transect along the lighted road in Vlasina Stojkovićeva (Fig. 2b) $\left(42.691016^{\circ} \mathrm{N}, 22.373792^{\circ} \mathrm{E}, 1356 \mathrm{~m}\right.$ a.s.1.) were unequivocally identified as those of Tadarida teniotis. This record represents the first finding of this species in Serbia.
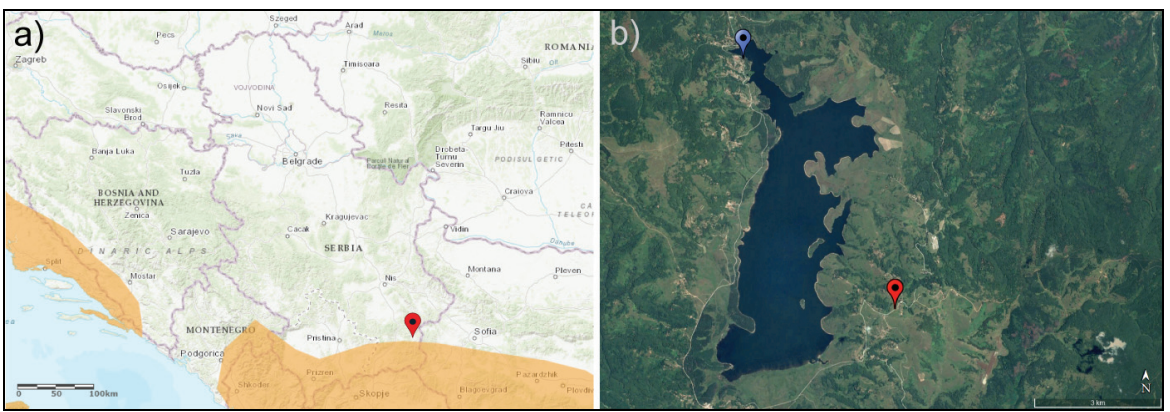

Fig. 2. - a) Geographic position of LOF "Vlasina" protected area on T. teniotis distribution map (modified Benda \& Piraccini 2016) b) Vlasina Lake with Vlasina Rid (blue pin) and Vlasina Stojkovićeva (red pin) locations.

T. teniotis has echolocation signals whose frequency is lower than that of any other European species, with long QCF calls at 9-14 kHz, which are thus often audible to the human ear and quite easy to recognise (Dietz \& Kiefer 2016). Signals that we recorded were of typical structure (Fig. 3), with the following parameters: QCF 10.6-11.4 kHz, start frequency 12.9$-15.3 \mathrm{kHz}$, end frequency $8.9-10.5 \mathrm{kHz}$, frequency of maximum energy $11.4-12.4 \mathrm{kHz}$, pulse duration 9.0-14.9 ms, inter-pulse interval $305-638 \mathrm{~ms}$. All the parameters fall within the range of $T$. teniotis call variability (Russo \& Jones 2002, Boonman et al. 2009). 


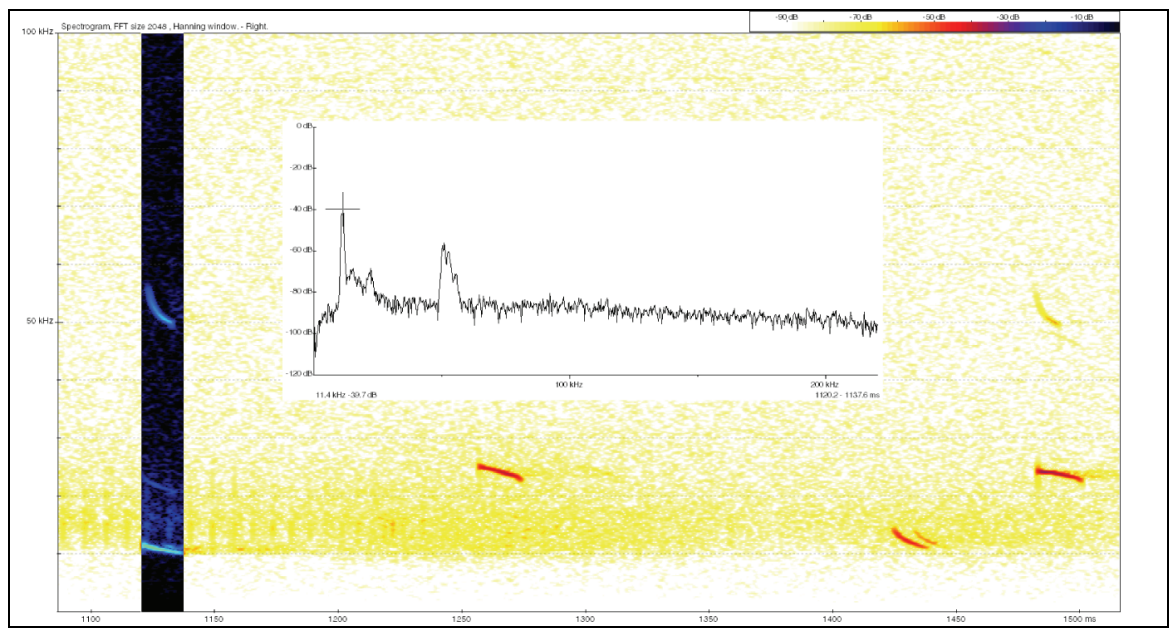

Fig. 3. - Echolocation calls of Tadarida teniotis recorded on $18^{\text {th }}$ October 2017 in Vlasina Stojkovićeva.

Given the roosting preferences of the species, no potential natural roosts (such as rocks, cliffs and caves) are present in the immediate vicinity of the Vlasina Lake, where the signal was recorded. Nevertheless, the bat is capable of flying long distances (up to $100 \mathrm{~km}$ ) in a single night (Dietz \& Kiefer 2016). Few localities in Bulgaria where T. teniotis is relatively common (Stoycheva et al. 2009), are located $200 \mathrm{~km}$ (Plovdiv) and $100 \mathrm{~km}$ (Rila mountains) from the Vlasina Lake, and it is possible that some of those animals sometimes visit south-eastern parts of Serbia. However, potential roosts in areas closer to our locality are plentiful. Future research of this species in Serbia is necessary to find out whether it roosts, breeds and/or hibernates in Serbia, or individuals of this species just commute and/or forage over the country's territory. Higher sampling efforts should be made in southern and south-eastern parts of Serbia, since the presence of this species was expected and confirmed in these parts of the country.

Tadarida teniotis was recorded for the first time in Serbia during our research. Until now, bat fauna of Serbia counted 30 species (Budinski et al. 2016, Paunović 2016), and with this finding the number rises to 31 .

\section{Acknowledgements}

We would like to thank the Protected Landscape "Vlasina" for their invitation and financial and logistical support in the field, as well as the Institute for Biological Research "Siniša Stanković" and the Natural History Museum in Belgrade. The authors are also grateful for the financial support provided by the Ministry of Environmental Protection of Serbia (project number 401-00-200/2016-17, project title "Monitoring of Bat 
Populations and Roost in Serbia"). The research of Branka Pejić was supported by the scholarship provided by the Ministry of Science, Education and Technological Development of Serbia.

\section{REFERENCES}

Belij, S., Nešić, D. (2014): Relief: geomorphological characteristics. In: Belij, S. (ed.): Landscape of Outstanding Features Vlasina: 19-32. - Institute for Nature Conservation of Serbia, Belgrade and PE Surdulica Municipality Land Development Directorate, Surdulica.

Benda, P., Piraccini, R. (2016): Tadarida teniotis. The IUCN Red List of Threatened Species 2016. - e.T21311A22114995 http://dx.doi.org/10.2305/ IUCN.UK.2016-2.RLTS.T21311A22114995.en Downloaded on 07.11.2017.

Boonman, A., Dietz, C., Koselj, K., Runkel, V., Russo, D., Siemers, B. (2009): Limits of echolocation calls of European bats, English version May 2009. http://www.batecho.eu/afbeeldingen/tableengvMay2009.pdf Downloaded on 05.08.2010.

Budinski, I., Karapandža, B., Josipović, V., Jovanović, J., Paunović, M. (2016): The first record of alpine long-eared bat Plecotus macrobullaris in Serbia. Turkish Journal of Zoology 40(3): 984-988.

Ciechanowski, M., Sachanowicz, K., Rachwald, A., Benda, P. (2005): First records of Tadarida teniotis (Rafinesque, 1814) (Chiroptera, Molossidae) from Serbia and Montenegro and from Bosnia and Herzegovina. - Mammalia 69(2): 257-260.

Dietz, C., Kiefer, A. (2016): Bats of Britain and Europe: 1-398. - Bloomsbury Publishing, United Kingdom.

Dokić, L. (1883): Analitički i sistematski pregled životinja u Kraljevini Srbiji. I deo, Kičmenjaci: 1-99. - Kraljevsko-Srpska državna štamparija, Beograd. [In Serbian]

Domazetović, Z., Hamidović, D. (2014): Sixth National Report on the Implementation of the Agreement - Croatia. - UNEP/EUROBATS Secretariat, Bonn. Inf.EUROBATS.MoP7.12. http://www.eurobats.org/sites/default/files/ documents/ pdf/National_Reports/nat_rep_Croa_2014.pdf Downloaded on 10.11.2017.

Marques, T., Rainho, A., Carapuco, M., Oliveira, P., Palmeirim, J. (2004): Foraging behavior and habitat use by the European free-tailed bat Tadarida teniotis. - Acta Chiropterologica 6(1): 99-110.

Micevski, N., Presetnik, P., Micevski, B., Celuch, M. (2014): Contribution to the knowledge of the Macedonian bat fauna. - Vespertilio 17: 103-114.

Milanolo, S., Pašić, J., Karapandža, B., Mulaomerović, J., Presetnik, P. (2017): Novi nalazi golorepog šišmiša (Tadarida teniotis) u Bosni i Hercegovini i prateća zapažanja. - Hypsugo 2(1): 42-45. In Serbian

Nedeljković, D., Lazarević, P., Nikolić, V. (2014): Flora and vegetation. In: Belij, S. (ed.): Landscape of Outstanding Features Vlasina: 51-64. - Institute for 
Nature Conservation of Serbia, Belgrade and PE Surdulica Municipality Land Development Directorate, Surdulica.

Pančić, J. (1869): Građa za faunu Kneževine Srbije. In: Glasnik Srpskog učenog društva 9(26): 62-103. - Beograd. [In Serbian]

Pandourski, I. (2014): Records of European free-tailed bat Tadarida teniotis (Rafinesque, 1814) (Mammalia: Chiroptera) in Bulgaria. - ZooNotes 52: 1-3.

Paunović, M. (2016): Rasprostanjenje, ekologija i centri diverziteta slepih miševa (Mammalia, Chiroptera) u Srbiji: 1-475. - Biološki fakultet Univerziteta u Beogradu. PhD thesis [in Serbian]

Paunović, M., Karapandža, B., Ivanović, S. (2011): Slepi miševi i procena uticaja na životnu sredinu - Metodološke smernice za procenu uticaja na životnu sredinu i stratešku procenu uticaja na životnu sredinu: 1-142. - Društvo za očuvanje divljih životinja „MUSTELA“, Beograd. [In Serbian]

Presetnik, P., Paunović, M., Karapandža, B., Đurović, M., Ivanović, Č., Ždralević, M., Benda, P., Budinski, I. (2014): Distribution of bats (Chiroptera) in Montenegro. - Vespertilio 17: 129-156.

Ramaj, E. (2014): National Implementation Report of Agreement on the conservation of populations of European bats - Albania. - UNEP/EUROBATS Secretariat, Bonn. - Inf.EUROBATS.MoP7.9. http://www.eurobats.org/sites/ default/files/documents/pdf/National_Reports/Inf.MoP7_.9-National\%20Imple mentation\%20Report\%20of\%20Albania.pdf Downloaded on 16.11.2017.

Russo, D., Jones, G. (2002): Identification of twenty-two bat species (Mammalia: Chiroptera) from Italy by analysis of time-expanded recordings of echolocation calls. - Journal of Zoology 258: 91-103.

Stoycheva, S., Georgiev, D., Pandourski, I., Tilova, E. (2009): Bat diversity in two large towns of the Upper Thrace, Bulgaria (Chiroptera). - Lynx, n. s. 40: 83-93.

\title{
ПРВИ НАЛАЗ СРЕДОЗЕМНОГ РЕПАША TADARIDA TENIOTIS (RAFINESQUE, 1814) У СРБИЈИ
}

\author{
БРАНКА ПЕЈИЋ, ИВАНА БУДИНСКИ, БРАНКО КАРАПАНЏА, \\ МИЛАН ПАУНОВИЋ
}

Средоземни репаш, Tadarida teniotis (Rafinesque, 1814) је врста слепог миша из породице Molossidae, распрострањена углавном на подручју Медитерана. Припадници ове врсте користе склоништа у пукотинама тешко доступних литица и стена, лете брзо и високо изнад тла, и способни су за дуге летове. Будући да је T. teniotis забележена у суседним државама и да у Србији постоје за њу погодна станишта, присуство ове врсте на територији Србије је било очекивано. 
На подручју заштићеног природног добра Предео изузетних одлика „Власина“ вршена је инвентаризација фауне слепих мишева у периоду 2015-2017. године. У вече 18. октобра 2017. године на локалитету Власина Стојковићева (42.691016 ${ }^{\circ}$ северне географске ширине, $22.373792^{\circ}$ источне географске дужине, 1356 м н.в.) применом методе ултразвучне аудиодетекције дефинитивно је потврђено присуство врсте T. teniotis, што представља њен први налаз у Србији. Овим је укупан број врста фауне слепих мишева Србије повећан на 31. Даља истраживања су неопходна како би се утврдило да ли постоје склоништа ове врсте, да ли се репродукује и/или хибернира на територији Србије. 